\title{
Qualitative changes with age of proteoglycans of human lumbar discs
}

\author{
PAMELA ADAMS AND HELEN MUIR \\ From the Kennedy Institute of Rheumatology, London
}

\begin{abstract}
Adams, P., and Muir, H. (1976). Annals of the Rheumatic Diseases, 35, 289-296. Qualitative changes with age of proteoglycans of human lumbar discs. A detailed study of the biochemistry of each of the lower lumbar intervertebral discs from 3 spines aged 8,16 , and 44 years has shown progressive changes down the spine in a number of biochemical parameters. These were most apparent in the 44-year-old spine. The chemical composition of proteoglycans of the nucleus pulposus and of its constituent proteoglycans differed from those of the corresponding annulus fibrosus of all three spines. The interaction of proteoglycans with collagen, as assessed by extractability, changed markedly with advancing age, while the molecular size of the proteoglycans from both regions decreased and their keratan sulphate content increased. These changes would be expected to affect the mechanical properties of the disc.
\end{abstract}

The overall chemical composition of both the nucleus pulposus and the annulus fibrosus of the human intervertebral disc, and the composition of the constituent proteoglycans have been shown to change with age (Lyons and others, 1964, 1966; Gower and Pedrini, 1969). The chief macromolecular comporents of intervertebral discs are collagen and proteoglycans providing, respectively, tensile strength and resistance to compression.

Proteoglycans of hyaline cartilage are heterogeneous in molecular size and composition and as isolated may be classified into aggregated and nonaggregated groups (Tsiganos, Hardingham, and Muir, 1971; Hascall and Sajdera, 1969). Proteoglycan aggregates are of large hydrodynamic size and on gel chromatography are excluded from Sepharose 2B, whereas nonaggregated proteoglycans are retarded as they are of smaller hydrodynamic size (Tsiganos and others, 1971; Hardingham and Muir, 1972, 1974). Aggregated proteoglycans have high sedimentation coefficients (Hascall and Sajdera, 1969) and are formed by the association of many proteoglycan molecules with a single chain of hyaluronic acid (Hardingham and Muir, 1972), the complex being stabilized (Hardingham and Muir, 1975) by a 'glycoprotein link' fraction (Gregory, 1973). In contrast, proteoglycans which are not aggregated have relatively low sedimentation coefficients (Hascall and Sajdera, 1969) and do not interact with hyaluronic acid (Hardingham and Muir, 1972, 1974).
In previous studies of articular cartilage, proteoglycans were extracted by a standard sequential procedure in which salts of increasing ionic strength were used. A similar procedure was adopted here, as it had been shown that the proportion and quality of proteoglycans extracted by each solution were different and changed during development (Simunek and Muir, 1972a) and also in pathological conditions (Simunek and Muir, 1972b; McDevitt and Muir, 1974). The limiting viscosity number of proteoglycans of nucleus pulposus has been shown to be less in herniated than in normal discs and to decrease with age (Lyons and others, 1966) which, it was suggested, might have arisen from some degradation of proteoglycans.

Assessment of the quality, particularly of the hydrodynamic size, of proteoglycans extracted from human nuclei pulposi and annuli fibrosi, therefore formed a major part of this study.

\section{Materials and methods}

ANALYTICAL METHODS

Uronic acid was determined by an automated modification (Heinegard, 1973) of the method of Bitter and Muir (1962) using glucuronolactone as a standard. Hydroxyproline was measured by an automated modification of the method of Woessner (1961); samples were hydrolysed in $6 \mathrm{~N} \mathrm{HCl}$ at $105^{\circ} \mathrm{C}$ for 24 hours using $1 \mathrm{ml}$ of acid per $5 \mathrm{mg}$ of dry tissue. Excess acid was removed by rotary evaporation and the sample dissolved in a 
known volume of water before analysis. Collagen contents were calculated using a factor of 7.55.

For the determination of glucosamine/galactosamine molar ratios, samples containing between 10 and $20 \mu \mathrm{g}$ uronic acid were hydrolysed in $8 \mathrm{~N} \mathrm{HCl}$ for 3 hours at $95^{\circ} \mathrm{C}$ in tubes sealed under vacuum (Swann and Balazs, 1966). Excess acid was then removed by rotary evaporation and $400 \mu \mathrm{l}$ water added to the dry hydrolysates, and the samples applied to the short column of a Locarte automated amino acid analyser.

\section{TISS UES}

The lower lumbar intervertebral discs of an 8-year-old and 16-year-old male and a 44-year-old female were used. The discs of the 8 and 16-year-old spines appeared to be healthy as assessed by $x$-ray and histological examination, but those of the 44 year old had slight degenerative changes especially in the lower discs. Immediately after routine post-mortem examination the intervertebral discs of the 16 and 44-year-old spines were dissected from the vertebral bodies and the nucleus pulposus and annulus fibrosus of each disc separated; these tissues were stored frozen at $-20^{\circ} \mathrm{C}$ until required for analysis. This dissection was performed on the 8-year-old spine immediately before analysis, the spine having been frozen intact after the post-mortem examination.

\section{EXTRACTION OF PROTEOGLYCANS}

Each nucleus and annulus was chopped into pieces of about $3 \mathrm{~mm}^{2}$, except for the gel-like nuclei of young discs which were pulled apart into small globular pieces. A small amount of tissue was retained for chemical analysis and the remainder suspended in ten times its weight of cold $0.15 \mathrm{~mol} / 1$ sodium acetate $\mathrm{pH} 6.8$ and agitated on a mechanical roller for 2 hours at $4^{\circ} \mathrm{C}$. The extract was filtered through glass wool and the residue washed with a little of the extracting solution. The filtrate and washings were combined and the residue was resuspended in ten times its weight of $3 \mathrm{~mol} / 1 \mathrm{MgCl}_{2} \mathrm{pH} 7.0$ and extracted for 24 hours at $4^{\circ} \mathrm{C}$. This extract was filtered and the residue washed as above and then resuspended in $4 \mathrm{~mol} / 1$ guanidinium chloride $-0.05 \mathrm{~mol} / 1$ sodium acetate $\mathrm{pH}$ 4.5 and extracted for a further 24 hours at $4^{\circ} \mathrm{C}$. The extract was filtered and the washed residue soaked overnight in distilled water to remove excess guanidinium chloride, in readiness for papain digestion. The annuli fibrosi of the 16-year-old male spine were divided into outer and inner regions before the extractions.

PURIFICATION AND ANALYIIS OF PROTEOGLYCANS The $3 \mathrm{~mol} / 1 \mathrm{magnesium}$ chloride or $4 \mathrm{~mol} / 1$ guanidinium chloride extracts were dialysed against water overnight, and a sample of the dialysed extracts and of the sodium acetate extracts retained for the assay of uronic acid. Proteoglycans were further purified by precipitation with 9-aminoacridine hydrochloride and converted to their sodium salts as described by Tsiganos and Muir (1969a) except that the exchange resin used was Dowex-50 ( Na form). Glucosamine/galactosamine molar ratios of purified proteoglycans were estimated after hydrolysis.

GEL CHROMATOGRAPHY OF PROTEOGLYCANS

Samples of purified proteoglycans containing about $1 \mathrm{mg}$ uronic acid were dissolved in $1 \mathrm{ml}$ of $0.5 \mathrm{~mol} / 1$ sodium acetate $\mathrm{pH} 6 \cdot 8$, and applied to a column $(160 \mathrm{~cm} \times 1.5$ cm) of Sepharose 2B (Pharmacia, Uppsala, Sweden) which was eluted upwards with $0.5 \mathrm{~mol} / 1$ sodium acetate $\mathrm{pH} 6.8$ at $4^{\circ} \mathrm{C}$ at a rate of $8 \mathrm{ml} / \mathrm{h}$ using a peristaltic pump. Fractions containing about $2.5 \mathrm{ml}$ were collected and their uronic acid contents determined.

CHEMICAL ANALYSIS OF TISSUES

For total chemical analyses portions were taken from a random sample of the nucleus and from a section cut radially across the annulus. In those discs where serial sections were cut across from the inner to the outer edge of the annulus, these were taken at a regular measured distance from the outer boundary. All samples for chemical analysis were dried to constant weight in vacuo over $\mathrm{P}_{2} \mathrm{O}_{5}$ at $80^{\circ} \mathrm{C}$.

PAPAIN DIGESTION

Samples of starting tissue dried to constant weight, or washed residual tissue after guanidinium chloride extraction, were suspended in 5 times their weight of $0.2 \mathrm{~mol} / \mathrm{l}$ sodium acetate $\mathrm{pH} 5.7$ containing $0.02 \mathrm{~mol} / 1$ cysteine hydrochloride and $0.004 \mathrm{~mol} / \mathrm{l}$ EDTA and incubated overnight at $55-60^{\circ} \mathrm{C}$ with crystalline papain (B.D.H. Biochemicals) using $0.5 \mathrm{mg} / \mathrm{g}$ wet weight of tissue. The very small amount of undigested material that remained was removed by filtration and the filtrate dialysed against water for $\mathbf{4 8}$ hours, in heated visking tubing (to reduce its porosity, Callanan, Carroll, and Mitchell, 1957). The uronic acid content, and in some cases the glucosamine/galactosamine molar ratios, were determined.

\section{Results}

\section{EXTRACTION}

The proportion of the total proteoglycan extracted by solutions of increasing ionic strength, using the standardized three-step procedure, provided a rough assessment of the physical state of the tissue and quality of the constituent proteoglycans. Brief extraction with $0.15 \mathrm{~mol} / \mathrm{l}$ sodium acetate removes mainly those proteoglycans that are not associated with other constituents of the tissue or present as aggregates. The latter are largely extracted by $3 \mathrm{~mol} / 1 \mathrm{MgCl}_{2}$ and $4 \mathrm{~mol} / \mathrm{l}$ guanidinium chloride. The proteoglycans remaining in the residue after the three extractions may be firmly associated with collagen or physically entrapped in the collagen network, and therefore the proportion of these is roughly correlated with the collagen content of the tissue. As the nuclei were less collagenous than the annuli, less of the total proteoglycans remained in the residue of the nuclei and a higher proportion were extracted with $0.15 \mathrm{~mol} / 1$ sodium acetate (Tables I-III). Unlike the discs of older spines, there was uniformity between the discs of the 8-year-old spine in the extraction of proteoglycans. About half the total proteoglycan was extracted from the nuclei with $0.15 \mathrm{~mol} / 1$ sodium acetate, and negligible amounts were left in the residue after the three extraction steps (Table I), but as the annuli contained more collagen, less than $20 \%$ of the total proteoglycan was extracted by $0.15 \mathrm{~mol} / \mathrm{l}$ sodium 
Table I Amount of uronic acid in proteoglycan extracts and residue of nuclei pulposi and annuli fibrosi of 8-year-old male

\begin{tabular}{|c|c|c|c|c|}
\hline \multirow[b]{2}{*}{ Disc } & \multicolumn{4}{|c|}{$\%$ of total uronic acid in tissue } \\
\hline & $\begin{array}{l}0.15 \mathrm{~mol} / \mathrm{l} \\
\text { sodium } \\
\text { acetate }\end{array}$ & $3 \mathrm{~mol} / \mathrm{l} \mathrm{MgCl}_{2}$ & $\begin{array}{l}4 \text { molll } \\
\text { guanidinium } \\
\text { chloride }\end{array}$ & Residue \\
\hline $\begin{array}{l}\text { Extract } \\
\text { L2/L3 } \\
\text { L3/L4 } \\
\text { L4/L5 } \\
\text { L5/S1 }\end{array}$ & $\begin{array}{l}\text { posi } \\
51 \cdot 8 \\
64 \cdot 0 \\
53 \cdot 0 \\
46 \cdot 0\end{array}$ & $\begin{array}{l}42 \cdot 6 \\
28 \cdot 8 \\
31 \cdot 6 \\
46 \cdot 0\end{array}$ & $\begin{array}{r}5 \cdot 4 \\
6 \cdot 9 \\
14 \cdot 0 \\
7 \cdot 8\end{array}$ & $\begin{array}{l}0 \cdot 2 \\
0 \cdot 2 \\
1 \cdot 5 \\
0 \cdot 2\end{array}$ \\
\hline $\begin{array}{l}\text { Extrac } \\
\mathrm{L} 2 / \mathrm{L3} \\
\mathrm{L} 3 / \mathrm{L} 4 \\
\mathrm{~L} 4 / \mathrm{L5} \\
\mathrm{L} 5 / \mathrm{S} 1\end{array}$ & $\begin{array}{l}\text { osi } \\
15 \cdot 0 \\
19 \cdot 7 \\
16 \cdot 4 \\
15 \cdot 0\end{array}$ & $\begin{array}{l}35 \cdot 0 \\
30 \cdot 9 \\
24 \cdot 4 \\
36 \cdot 2\end{array}$ & $\begin{array}{l}36 \cdot 0 \\
38 \cdot 7 \\
41 \cdot 7 \\
40 \cdot 0\end{array}$ & $\begin{array}{r}14 \cdot 0 \\
10 \cdot 7 \\
17 \cdot 5 \\
9 \cdot 0\end{array}$ \\
\hline
\end{tabular}

Table II Amount of uronic acid in proteoglycan extracts and residue of nuclei pulposi and annuli fibrosi of 16-year-old male

\begin{tabular}{|c|c|c|c|c|}
\hline \multirow[b]{2}{*}{ Disc } & \multicolumn{4}{|c|}{$\%$ of total uronic acid in tissue } \\
\hline & $\begin{array}{l}0.15 \mathrm{~mol} / \mathrm{l} \\
\text { sodium } \\
\text { acetate }\end{array}$ & $3 \mathrm{~mol} / \mathrm{l} \mathrm{MgCl}$ & $\begin{array}{l}4 \text { mol/l } \\
\text { guanidinium } \\
\text { chloride }\end{array}$ & Residue \\
\hline $\begin{array}{l}\text { Extract } \\
\text { L2/L3 } \\
\text { L3/L4 } \\
\text { L4/L5 } \\
\text { L5/S1 }\end{array}$ & $\begin{array}{l}\text { posi } \\
31 \cdot 0 \\
52 \cdot 2 \\
15 \cdot 0 \\
54 \cdot 1\end{array}$ & $\begin{array}{l}48 \cdot 1 \\
37 \cdot 6 \\
58 \cdot 8 \\
31 \cdot 2\end{array}$ & $\begin{array}{r}16.9 \\
7.8 \\
20.0 \\
10.9\end{array}$ & $\begin{array}{l}4 \cdot 0 \\
2 \cdot 5 \\
6 \cdot 2 \\
3 \cdot 8\end{array}$ \\
\hline $\begin{array}{l}\text { Extract } \\
\text { L2/L3 } \\
\text { L3/L4 } \\
\text { L4/L5 } \\
\text { L5/S1 }\end{array}$ & $\begin{array}{l}\text { osi } \\
25 \cdot 2 \\
18 \cdot 1 \\
19 \cdot 5 \\
24 \cdot 3\end{array}$ & $\begin{array}{l}29 \cdot 3 \\
45 \cdot 0 \\
34 \cdot 1 \\
37 \cdot 1\end{array}$ & $\begin{array}{l}33 \cdot 3 \\
19 \cdot 5 \\
27 \cdot 5 \\
23 \cdot 5\end{array}$ & $\begin{array}{l}12 \cdot 1 \\
17 \cdot 1 \\
18 \cdot 8 \\
15 \cdot 9\end{array}$ \\
\hline
\end{tabular}

Table III Amount of uronic acid in proteoglycan extracts and residue of nuclei pulposi and annuli fibrosi of 44-year-old female

\begin{tabular}{|c|c|c|c|c|}
\hline \multirow[b]{2}{*}{ Disc } & \multicolumn{4}{|c|}{$\%$ of total uronic acid in tissue } \\
\hline & $\begin{array}{l}0.15 \mathrm{~mol} / \mathrm{l} \\
\text { sodium } \\
\text { acetate }\end{array}$ & $3 \mathrm{~mol} / \mathrm{l} \mathrm{MgCl}$ & $\begin{array}{l}4 \text { mol/l } \\
\text { guanidinium } \\
\text { chloride }\end{array}$ & Residue \\
\hline $\begin{array}{l}\text { Extracts } \\
\text { T12/L1 } \\
\text { L1/L2 } \\
\text { L2/L3 } \\
\text { L3/L4 } \\
\text { L4/L5 } \\
\text { L5/S1 }\end{array}$ & $\begin{array}{c}\text { posi } \\
74 \cdot 5 \\
74 \cdot 0 \\
72 \cdot 5 \\
72 \cdot 5 \\
63 \cdot 7 \\
67 \cdot 9\end{array}$ & $\begin{array}{r}10 \cdot 7 \\
10 \cdot 5 \\
15 \cdot 2 \\
10 \cdot 0 \\
20 \cdot 3 \\
9.9\end{array}$ & $\begin{array}{l}2 \cdot 2 \\
4 \cdot 0 \\
3 \cdot 2 \\
5 \cdot 1 \\
5 \cdot 0 \\
6 \cdot 6\end{array}$ & $\begin{array}{r}12 \cdot 6 \\
12 \cdot 0 \\
9 \cdot 0 \\
12 \cdot 6 \\
11 \cdot 0 \\
15 \cdot 7\end{array}$ \\
\hline $\begin{array}{l}\text { Extracts } \\
\text { T12/L1 } \\
\text { L1/L2 } \\
\text { L2/L3 } \\
\text { L3/L4 } \\
\text { L4/L5 } \\
\text { L5/S1 }\end{array}$ & $\begin{array}{l}\text { osi } \\
34 \cdot 4 \\
34 \cdot 9 \\
43 \cdot 8 \\
30 \cdot 0 \\
35 \cdot 3 \\
24 \cdot 2\end{array}$ & $\begin{array}{l}18 \cdot 7 \\
24 \cdot 2 \\
13 \cdot 5 \\
14 \cdot 6 \\
15 \cdot 5 \\
20 \cdot 0\end{array}$ & $\begin{array}{l}17 \cdot 2 \\
17 \cdot 4 \\
17 \cdot 1 \\
18 \cdot 5 \\
14 \cdot 2 \\
19 \cdot 8\end{array}$ & $\begin{array}{l}29 \cdot 8 \\
23 \cdot 6 \\
25 \cdot 6 \\
36 \cdot 8 \\
34 \cdot 7 \\
36 \cdot 0\end{array}$ \\
\hline
\end{tabular}


acetate from the annuli, $36-42 \%$ was removed by the third extract, and $9-18 \%$ remained in the residue (Table I).

There were small differences in the extraction of proteoglycans between the discs of the 16-year-old spine but there was a general resemblance with the discs of the 8-year-old spine (Table II). On the other hand, the discs of the 44-year-old spine showed some major differences from those of younger spines, in particular a much higher proportion of the total proteoglycan was extracted by $0.15 \mathrm{~mol} / 1$ sodium acetate from the annuli as well as the nuclei, and there were distinct differences between discs (Table III).
The 44-year-old spine also differed from the younger ones in that the collagen content of the discs increased down the spine (Table IV) and consequently the proportion of the total proteoglycan that remained in the residue increased in parallel (Table III). A more detailed analysis of the annuli fibrosi of the 16 and 44-year-old spines was therefore carried out. Only in the outer region of the annuli fibrosi of the 16-year-old spine was there an increase in inextractable proteoglycan downwards (Table V). There was less collagen in the inner region and hence less of the total proteoglycan was left in the residue of the inner region after the three extractions (Table V).

Table IV Collagen and uronic acid contents of inner, middle, and outer regions of annuli fibrosi of 44-year-old spine

\begin{tabular}{|c|c|c|c|c|c|}
\hline \multirow[b]{3}{*}{ Disc } & & \multicolumn{4}{|c|}{$\%$ of dry weight } \\
\hline & & \multicolumn{4}{|c|}{ Regions of annulus } \\
\hline & & Inner & Middle & Outer & \\
\hline $\mathrm{T} 12 / \mathrm{L} 1$ & $\begin{array}{l}\text { Collagen } \\
\text { Uronic acid }\end{array}$ & $\begin{array}{r}15 \cdot 0 \\
6 \cdot 2\end{array}$ & $\begin{array}{r}30 \cdot 0 \\
5 \cdot 8\end{array}$ & $\begin{array}{r}38 \cdot 0 \\
2 \cdot 3\end{array}$ & \\
\hline L1/L2 & $\begin{array}{l}\text { Collagen } \\
\text { Uronic acid }\end{array}$ & $\begin{array}{r}15 \cdot 0 \\
7 \cdot 2\end{array}$ & $\begin{array}{r}30 \cdot 0 \\
5 \cdot 8\end{array}$ & $\begin{array}{r}46 \cdot 0 \\
2 \cdot 5\end{array}$ & 윰 \\
\hline $\mathrm{L} 2 / \mathrm{L} 3$ & $\begin{array}{l}\text { Collagen } \\
\text { Uronic acid }\end{array}$ & $\begin{array}{c}19 \cdot 0 \\
6 \cdot 85\end{array}$ & $\begin{array}{r}43 \cdot 0 \\
5 \cdot 1\end{array}$ & $\begin{array}{r}46 \cdot 0 \\
2 \cdot 4\end{array}$ & ఫ্ \\
\hline $\mathrm{L} 3 / \mathrm{L} 4$ & $\begin{array}{l}\text { Collagen } \\
\text { Uronic acid }\end{array}$ & $\begin{array}{r}20 \cdot 0 \\
6 \cdot 3\end{array}$ & $\begin{array}{r}35 \cdot 0 \\
4 \cdot 1\end{array}$ & $\begin{array}{r}49 \cdot 0 \\
2 \cdot 5\end{array}$ & $\stackrel{\partial}{\rightleftharpoons}$ \\
\hline L4/L5 & $\begin{array}{l}\text { Collagen } \\
\text { Uronic acid }\end{array}$ & $\begin{array}{r}30 \cdot 0 \\
7 \cdot 2\end{array}$ & $\begin{array}{r}48 \cdot 0 \\
6 \cdot 1\end{array}$ & $\begin{array}{r}48 \cdot 0 \\
3 \cdot 0\end{array}$ & \\
\hline L5/S1 & $\begin{array}{l}\text { Collagen } \\
\text { Uronic acid }\end{array}$ & $\begin{array}{r}32 \cdot 0 \\
6 \cdot 0\end{array}$ & $\begin{array}{r}49 \cdot 0 \\
4 \cdot 9\end{array}$ & $\begin{array}{r}58 \cdot 0 \\
2 \cdot 5\end{array}$ & \\
\hline
\end{tabular}

Table $\mathbf{V}$ Amount of uronic acid in proteoglycan extracts and residues of inner and outer annuli fibrosi of 16-year-old specimen and hexosamine composition of proteoglycans in extracts of L5/S1

\begin{tabular}{|c|c|c|c|c|}
\hline \multirow[b]{2}{*}{ Disc } & \multicolumn{4}{|c|}{$\%$ of total uronic acid in tissue } \\
\hline & $\begin{array}{l}0.15 \mathrm{~mol} / \mathrm{l} \\
\text { sodium } \\
\text { acetate }\end{array}$ & $3 \mathrm{~mol} / \mathrm{l} \mathrm{MgCl}$ & $\begin{array}{l}4 \text { mol/l } \\
\text { guanidinium } \\
\text { chloride }\end{array}$ & Residue \\
\hline \multicolumn{5}{|c|}{ Extracts of inner annuli } \\
\hline $\begin{array}{l}\text { L2/L3 } \\
\text { L3/L4 } \\
\text { L4/L5 } \\
\text { L5/S1 }\end{array}$ & $\begin{array}{l}41 \cdot 0 \\
18 \cdot 6 \\
23 \cdot 5 \\
29 \cdot 4\end{array}$ & $\begin{array}{l}31 \cdot 1 \\
56 \cdot 9 \\
42 \cdot 3 \\
40 \cdot 2\end{array}$ & $\begin{array}{l}13 \cdot 4 \\
13 \cdot 7 \\
23 \cdot 4 \\
21 \cdot 1\end{array}$ & $\begin{array}{r}7 \cdot 4 \\
11 \cdot 0 \\
10 \cdot 8 \\
9 \cdot 3\end{array}$ \\
\hline \multicolumn{5}{|c|}{ Glucosamine/galactosamine molar ratios of extracted proteoglycans } \\
\hline L5/S1 & 0.54 & 0.85 & 0.74 & 一 \\
\hline \multicolumn{5}{|c|}{ Extracts of outer annuli } \\
\hline $\begin{array}{l}\text { L2/L3 } \\
\text { L3/L4 } \\
\text { L4/L5 } \\
\text { L5/S1 }\end{array}$ & $\begin{array}{l}12 \cdot 5 \\
16 \cdot 1 \\
16 \cdot 8 \\
16 \cdot 1\end{array}$ & $\begin{array}{l}22 \cdot 3 \\
31 \cdot 0 \\
28 \cdot 4 \\
31 \cdot 8\end{array}$ & $\begin{array}{l}47 \cdot 1 \\
31 \cdot 8 \\
30 \cdot 4 \\
27 \cdot 4\end{array}$ & $\begin{array}{l}17 \cdot 5 \\
21 \cdot 1 \\
24 \cdot 4 \\
24 \cdot 7\end{array}$ \\
\hline \multicolumn{5}{|c|}{ Glucosamine/galactosamine molar ratios of extracted proteoglycons } \\
\hline $\mathbf{L} 5 / \mathbf{S} 1$ & 0.45 & 0.87 & 0.90 & - \\
\hline
\end{tabular}


In the 44-year-old spine the annuli fibrosi were dissected into three regions which were analysed separately. Table IV shows that as the collagen content increased outwards the uronic acid content decreased. The lowest disc of this spine was more collagenous than the others, the outer region consisting of about $60 \%$ collagen, and there was almost twice as much collagen in the inner region of this disc compared with the inner region of the first lumbar disc (Table IV). The proteoglycans of the lowest disc were less extractable compared with those in the discs above, and a higher proportion remained in the residue of the lowest disc (Table III; sum of the 3 regions).

\section{CHARACTERISTICS OF PROTEOGLYCANS}

In order to characterize and compare the proteoglycans from different regions and from different discs the ranges of molecular size were assessed by gel chromatography on Sepharose 2B, and the contents of keratan sulphate relative to chondroitin sulphate determined from the molar ratio of glucosamine to galactosamine (see Discussion).

It was found that for a given spine the gel chromatographic profiles of proteoglycans obtained from the nuclei of different discs were similar and this was also true of the proteoglycans of annuli. Thus although the profiles shown in Figs. 1 and 2 are derived from one disc of each spine, they are representative of the other discs. Moreover, it is notable that although the annulus fibrosus and nucleus pulposus are distinct anatomical regions the range of sizes of proteoglycans extracted from each region of a given spine was similar (Figs. 1 \& 2). This was also true of the proteoglycans extracted from the inner and outer regions of the annuli of

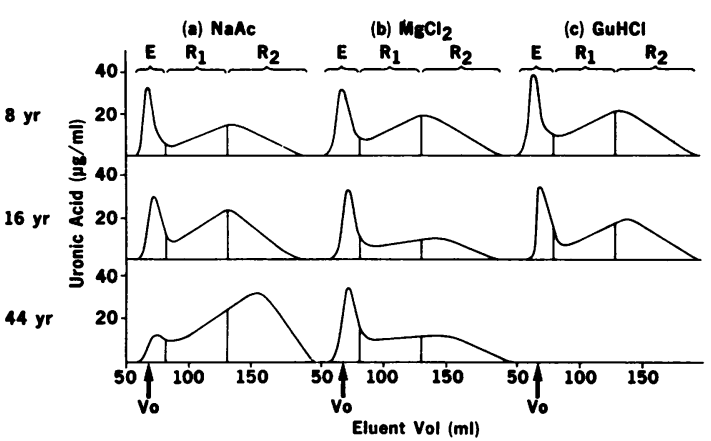

FIG. 1 Elution profiles of purified proteoglycans of nucleus pulposus from 8, 16, and 44-year-old spines. Proteoglycans were extracted with (a) $0 \cdot 15$ mol/l sodium

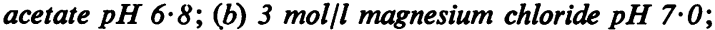
(c) 4 mol/l guandinium chloride $-0.05 \mathrm{~mol} / \mathrm{l}$ sodium acetate pH 4.5 and eluted from a column $(160 \mathrm{~cm} \times 1.5$ $\mathrm{cm}$ ) of Sepharose $2 B$. Vo is the void volume of the column the 16-year-old spine (Fig. 2). Furthermore, proteoglycans in the sequential extracts of tissues of younger spines had similar elution profiles.

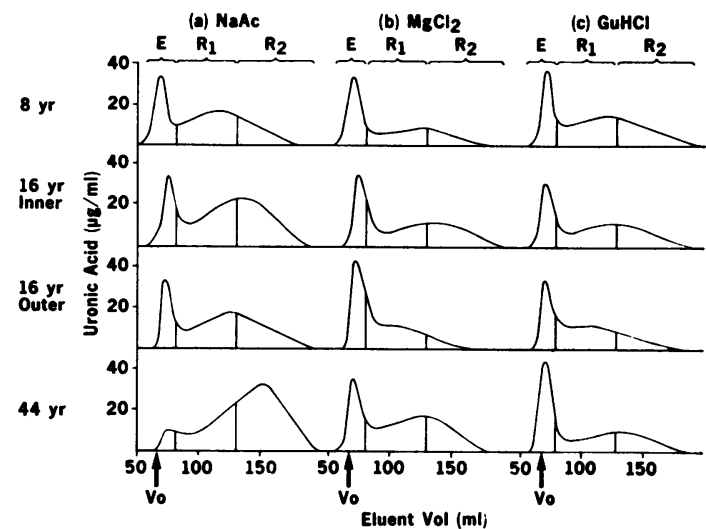

FIG. 2 Elution profiles of purified proteoglycans of whole annuli fibrosi of 8 and 44-year-old spines, and from the inner and outer regions of the annulus of a 16-year-old spine. Proteoglycans were extracted with (a) $0.15 \mathrm{~mol} / \mathrm{l}$ sodium acetate $\mathrm{pH} 6 \cdot 8$; (b) 3 mol/l magnesium chloride $\mathrm{pH}$ $7 \cdot 0 ;$ (c) 4 mol $/ l$ guanidinium chloride -0.05 mol $/ 1$ sodium acetate $\mathrm{pH} 4.5$ and eluted from a column $(160 \mathrm{~cm} \times 1.5$ $\mathrm{cm}$ ) of Sepharose $2 B$. Vo is the void volume of the column

The 44-year-old spine, however, was markedly distinct in this respect from the others in that the proteoglycans in the first extract $(0.15 \mathrm{~mol} / 1$ sodium acetate) were of much smaller average molecular size than those extracted subsequently (Figs. 1 \& 2). Almost none were excluded from the gel and a considerable proportion of those that penetrated the gel were of relatively small size (Figs. $1 \& 2$ ). Since over $70 \%$ of the proteoglycans of the nucleus and $25-40 \%$ of those of the annulus were removed in the first extract, a considerable proportion of the total proteoglycans of the discs of the 44-year-old spine were of small molecular size (Table IX).

The keratan sulphate and chondroitin sulphate contents of the proteoglycans were assessed from glucosamine:galactosamine molar ratios. When the tissues of the 4 lower discs of the 8-year-old spine (not the extracted proteoglycans) were analysed they had similar hexosamine compositions, although

Table VI Hexosamine composition of tissue: annuli fibrosi and nuclei pulposi of 8-year-old spine

Glucosamine/galactosamine molar ratios

\begin{tabular}{llll}
\cline { 3 - 3 } Disc & & Annuli fibrosi & Nuclei pulposi \\
\cline { 1 - 1 } L2/L3 & 0.79 & 0.35 \\
L3/L4 & 0.71 & 0.38 \\
L4/L5 & 0.64 & 0.40 \\
L5/S1 & 0.635 & 0.52
\end{tabular}


the molar ratios of the annuli and nuclei changed a little in opposite ways down the spine (Table VI). The hexosamine composition of proteoglycans in each successive extract was also similar, as shown for example for those of L5/S1 (Table VII).

In the 16-year-old spine likewise there were no consistent differences between discs but in this case the proteoglycans in the first extracts of nuclei and annuli contained relatively more chondroitin sulphate (lower glucosamine:galactosamine molar ratio) than did those in subsequent extracts (Tables V \& VII). This was most apparent with proteoglycans extracted from the outer region of the annuli (Table V).

The 44-year-old spine was distinct from the younger spines in showing considerable differences between discs in glucosamine: galactosamine molar ratios of proteoglycans in corresponding sequential extracts of nucleus and annulus (Table VIII). Since this ratio decreased in both regions of the disc down the spine the keratan sulphate content of proteoglycans was less in the lower than in the upper discs of this spine. Throughout, the proteoglycans extracted with sodium acetate contained much less keratan sulphate than those in subsequent extracts (Table VIII).

\section{Discussion}

As in other cartilaginous tissues (Simunek and Muir, 1972a, b; Brandt and Muir, 1971a, b) the proteoglycans of human nucleus pulposus and annulus fibrosus were heterogeneous and polydisperse.

To enable the results obtained with each spine to be compared, a standard time of extraction in each solution was used. Tissues were extracted in isoosmotic sodium acetate for $\mathbf{2}$ hours only to minimize enzymic degradation. Since little proteoglycan was left in the residue in the nucleus pulposus, it appears that proteoglycans are readily extracted from this tissue and a longer extraction with sodium acetate might well have brought into solution much more of the total uronic acid.

Iso-osmotic sodium acetate preferentially extracts from cartilage proteoglycans of the lower range of hydrodynamic size (Tsiganos and Muir, 1969b; Brandt and Muir, 1971a; Hardingham and Muir, 1974) and this might explain why it was so effective in extracting proteoglycans from the tissues of the 44-year-old spine which contained a higher proportion of smaller molecules than the tissues of the two younger spines (Figs. $1 \& 2$; Table IX). These proteoglycans may have resulted from degenerative

Table VII Hexosamine composition of proteoglycans in extracts of annuli fibrosi and nuclei pulposi of discs $(L 5 / S 1)$ from 8,16, and 44-year-old spines

\begin{tabular}{|c|c|c|c|c|c|c|}
\hline \multirow[b]{3}{*}{ Age of spine (years) } & \multicolumn{6}{|c|}{ Glucosamine/galactosamine molar ratios } \\
\hline & \multicolumn{3}{|c|}{ Extracts of annuli fibrosi } & \multicolumn{3}{|c|}{ Extracts of nuclei pulposi } \\
\hline & $\begin{array}{l}0.15 \mathrm{~mol} / \mathrm{l} \\
\text { sodium } \\
\text { acetate }\end{array}$ & $\begin{array}{l}3 \mathrm{~mol} / \mathrm{l} \\
\mathrm{MgCl}_{2}\end{array}$ & $\begin{array}{l}4 \text { mol/l } \\
\text { guanidinium } \\
\text { chloride }\end{array}$ & $\begin{array}{l}0.15 \mathrm{~mol} / \mathrm{l} \\
\text { sodium } \\
\text { acetate }\end{array}$ & $\begin{array}{l}3 \mathrm{~mol} / \mathrm{l} \\
\mathrm{MgCl}_{2}\end{array}$ & $\begin{array}{l}4 \text { mol/l } \\
\text { guanidinium } \\
\text { chloride }\end{array}$ \\
\hline $\begin{array}{r}8 \\
16 \\
44\end{array}$ & $\begin{array}{l}0.40 \\
0.51 \\
0.50\end{array}$ & $\begin{array}{l}0 \cdot 63 \\
0 \cdot 88 \\
0 \cdot 87\end{array}$ & $\begin{array}{l}0 \cdot 55 \\
0 \cdot 81 \\
1 \cdot 10\end{array}$ & $\begin{array}{l}0 \cdot 30 \\
0.47 \\
0.50\end{array}$ & $\begin{array}{l}0.35 \\
0.76 \\
1 \cdot 29\end{array}$ & $\begin{array}{l}0.38 \\
0.90 \\
1.97\end{array}$ \\
\hline
\end{tabular}

Table VII Hexosamine composition of extracted proteoglycans in annuli fibrosi and nuclei pulposi of 44-year-old spine

\begin{tabular}{|c|c|c|c|c|c|c|}
\hline \multirow[b]{3}{*}{ Disc } & \multicolumn{6}{|c|}{ Glucosamine/galactosamine molar ratios } \\
\hline & \multicolumn{3}{|c|}{ Extracts of annuli fibrosi } & \multicolumn{3}{|c|}{ Extracts of nuclei pulposi } \\
\hline & $\begin{array}{l}0.15 \mathrm{~mol} / \mathrm{l} \\
\text { sodium } \\
\text { acetate }\end{array}$ & $\begin{array}{l}3 \mathrm{~mol} / \mathrm{l} \\
\mathrm{MgCl}_{2}\end{array}$ & $\begin{array}{l}4 \text { mol/l } \\
\text { guanidinium } \\
\text { chloride }\end{array}$ & $\begin{array}{l}0.15 \mathrm{~mol} / \mathrm{l} \\
\text { sodium } \\
\text { acetate }\end{array}$ & $\begin{array}{l}3 \mathrm{~mol} / \mathrm{l} \\
\mathrm{MgCl}_{2}\end{array}$ & $\begin{array}{l}4 \text { mol } / l \\
\text { guanidinium } \\
\text { chloride }\end{array}$ \\
\hline $\begin{array}{l}\text { T12/L1 } \\
\text { L1/L2 } \\
\text { L2/L3 } \\
\text { L3/L4 } \\
\text { L4/L5 } \\
\text { L5/S1 }\end{array}$ & $\begin{array}{l}0.69 \\
0.64 \\
0.53 \\
0.55 \\
0.54 \\
0.50\end{array}$ & $\begin{array}{l}1 \cdot 17 \\
1 \cdot 12 \\
1 \cdot 12 \\
0 \cdot 99 \\
0 \cdot 97 \\
0 \cdot 87\end{array}$ & $\begin{array}{l}1 \cdot 44 \\
\overline{1} \cdot 22 \\
1 \cdot 25 \\
1 \cdot 24 \\
1 \cdot 10\end{array}$ & $\begin{array}{l}- \\
0.66 \\
0.66 \\
0.65 \\
0.65 \\
0.50\end{array}$ & $\begin{array}{l}1 \cdot 85 \\
2 \cdot 03 \\
2 \cdot 06 \\
1 \cdot 41 \\
1 \cdot 60 \\
1 \cdot 29\end{array}$ & $\begin{array}{l}\bar{Z} \\
\overline{2 \cdot 08} \\
\overline{1.97}\end{array}$ \\
\hline
\end{tabular}


changes like those in articular cartilage of lame pigs (Simunek and Muir, 1972b) or of dogs with experimentally induced osteoarthrosis (McDevitt and Muir, 1974). Those proteoglycans that were included in Sepharose 2B were of smaller average molecular size than the corresponding proteoglycans of younger discs and covered a wider range of sizes (Figs. $1 \& 2$; Table IX).

Table IX Combined results of 3 extracts: proportions of total proteoglycans of annuli fibrosi and nuclei pulposi of 8,16, and 44-year-old spines excluded and retarded on Sepharose $2 B$ gel chromatography

\begin{tabular}{|c|c|c|c|c|c|c|}
\hline \multirow[b]{3}{*}{$\begin{array}{c}\text { Age of spine } \\
\text { (years) }\end{array}$} & \multicolumn{6}{|c|}{$\%$ of total uronic acid } \\
\hline & \multicolumn{3}{|c|}{ Annuli fibrosi } & \multicolumn{3}{|c|}{ Nuclei pulposi } \\
\hline & $E_{1}$ & $R_{1}$ & $R_{2}$ & $E_{1}$ & $R_{1}$ & $R_{2}$ \\
\hline $\begin{array}{r}8 \\
16 \\
44\end{array}$ & $\begin{array}{l}38 \\
33 \\
24\end{array}$ & $\begin{array}{l}42 \\
39 \\
35\end{array}$ & $\begin{array}{l}20 \\
28 \\
41\end{array}$ & $\begin{array}{l}26 \\
24 \\
12\end{array}$ & $\begin{array}{l}45 \\
38 \\
31\end{array}$ & $\begin{array}{l}29 \\
38 \\
51\end{array}$ \\
\hline
\end{tabular}

Intervertebral discs are not entirely comparable with cartilaginous tissues in this respect, however, because $0.15 \mathrm{~mol} / \mathrm{l}$ sodium acetate also extracted considerable amounts of larger proteoglycans from younger discs. These proteoglycans were excluded from Sepharose 2B (Figs. $1 \&$ 2) and were therefore probably aggregated, because disaggregated proteoglycans are able to penetrate this gel (Hardingham and Muir, 1972, 1974) and there is evidence for proteoglycan aggregates in pig (Tsiganos and Muir, 1973) and human (Emes and Pearce, 1975) discs. There may therefore be little association of proteoglycans with collagen before maturity is reached, but it becomes stronger with age. Thus although the collagen contents of the 44 and 16-year-old discs were similar more proteoglycan remained in the residue of the 44-year-old tissues at the end of the extraction procedure. Somewhat different proteoglycans richer in glucosamine relative to galactosamine were present in older tissues (Table VII); these may be more strongly associated with collagen.

The limiting viscosity number of proteoglycans of intervertebral discs has been found to decrease with the age of the discs particularly when they were herniated (Lyons and others, 1964; 1966). This is in keeping with the apparent loss or diminution of proteoglycan aggregates in older tissues, as aggregation involves the interaction of many proteoglycan molecules with a single chain of hyaluronic acid which results in a large increase in relative viscosity (Hardingham and Muir, 1972; 1974). The loss of aggregates could arise either because there was too little hyaluronic acid in the tissues, or because the proteoglycans had lost their ability to interact with hyaluronate to form aggregates. Results of Hardingham and Adams (1976) suggest that there is more than enough hyaluronate in the disc to interact with the proteoglycan present and considerably more than in cartilage where it is almost entirely found in aggregates (Hardingham and Muir, 1974). If proteoglycans in older discs are unable to interact with hyaluronate they may have been partially degraded by enzymes released into the matrix, particularly if in degenerate discs cell necrosis has occurred. There is some evidence for neutral and acid proteases in intervertebral discs (Naylor, Shentall, and West, 1974) which could attack the protein core of proteoglycans or the protein-link component (Gregory, 1973) that stabilizes the proteoglycan-hyaluronate complex (Hardingham and Muir, 1975). Alternatively, proteoglycans of a different structure that do not interact with hyaluronate may be formed in older discs, as is implied from the increase in glucosamine: galactosamine molar ratios. In cartilage hyaluronate (which contains glucosamine) accounts for less than $1 \%$ of the total uronic acid (Hardingham and Muir, 1973; Hascall and Heinegard, 1974) and hence this molar ratio essentially reflects the relative proportions of keratan sulphate and chondroitin sulphate in proteoglycans. Although there appears to be somewhat more hyaluronate in intervertebral discs, glucosamine accounts for one-third to more than half of the total hexosamine in proteoglycans from older tissues (Table VIII). Only a small proportion would be attributable to hyaluronate and hence the increase in glucosamine:galactosamine molar ratios largely reflects the greater keratan sulphate content of proteoglycans of older tissues. Moreover, as with cartilage (Simunek and Muir, 1972a, b; McDevitt and Muir, 1974) the proportion of glucosamine increased in proteoglycans in sequential extracts particularly of older tissues (Tables VII \& VIII).

The proportion of the total proteoglycan that remained in the residue in general was related to the collagen content, but may also have been affected by the type of collagen in the tissue. Annulus fibrosus contains both type I and type II collagen (Eyre and Muir, 1974), type I collagen predominating in the outer regions (Eyre and Muir, 1976). In the 16-year-old spine the majority of proteoglycans were removed in the third extract from the outer region of the annulus, whereas they were mostly removed in the first two extracts from the inner region where only half as much of the total remained in the residue (Table V). Proteoglycans of the inner region consisted of a somewhat higher proportion of smaller molecules (Fig. 2) which may also be a factor contributing to the greater readiness with which they were extracted. 
The present results suggest that aging and/or mild degeneration is accompanied by a change in the quality of proteoglycans that leads to the enhanced association of some with collagen and diminished capacity of the remainder to form aggregates. Whether these changes are characteristic of normal aging or of pathological degeneration cannot be distinguished with the few spines examined. The observed changes, however, are likely to affect the mechanical performance of the disc considerably.

We thank Dr. B. Vernon-Roberts for the supply of tissue; Mr. R. J. F. Ewins for the amino sugar analyses; and the Arthritis and Rheumatism Council for the support of P.A

\section{References}

BrTter, T., AND MUIR, H. (1962) Analyt. Biochem., 4, 330 (A modified uronic acid carbazole reaction)

BRANDT, K. D., AND MUIR, H. (1971a) Biochem. J., 121, 261 (Heterogeneity of protein-polysaccharides of porcine articular cartilage- the sequential extraction of chondroitin sulphate-proteins with iso-osmotic neutral sodium acetate)

- - (1971b) Biochem. J., 123, 747 (Heterogeneity of protein-polysaccharides of porcine articular cartilagethe chondroitin sulphate proteins associated with collagen)

Callanan, M. J., Carroll, W. R., and Mitchell, E. R. (1957) J. biol. Chem., 229, 279 (Physical and chemical properties of protamine from the sperm of salmon (Oncorhynchus Tschaurytscha) I. Preformation and characterisation)

Emes, J. H., AND PeARCe, R. H. (1975) Biochem. J., 145, 549 (The proteoglycans of the human intervertebral disc)

EYRE, D. R., AND MUIR, H. (1974) FEBS Letters, 42, 192 (Collagen polymorphism: two molecular species in pig intervertebral disc)

,-- (1976) Biochem. J., 157, 267 (Types of I and II collagens in intervertebral disc)

GowER, W. E., AND PEDRINI, V. (1969) J. Bone Jt Surg., 51A, 1154 (Age related variations in protein-polysaccharides from human nucleus pulposus, annulus fibrosus, and costal cartilage)

GREGORY, J. D. (1973) Biochem. J., 133, 383 (Multiple aggregation factors in cartilage proteoglycans)

HARDINGHAM, T., AND ADAMS, P. (1976) Ibid., 159 (in press) (A method for the estimation of hyaluronate in the presence of other glycosaminoglycans and its application to human intervertebral discs)

- AND MUIR, H. (1972) Biochem. biophys. Acta, 279, 401 (The specific interaction of hyaluronic acid with cartilage proteoglycans)

,-- (1973) Biochem. Soc. Trans., 1, 282 (Hyaluronic acid in cartilage)

- (1974) Biochem. J., 139, 565 (Hyaluronic acid in cartilage and proteoglycan aggregation)

- (1975) Ann. rheum. Dis., 34, Suppl. 2, 26 (Structure and stability of proteoglycan aggregates)

Hascall, V. C., AND Heinegard, D. (1974) J. biol. Chem., 249, 4232 (Aggregation of cartilage proteoglycans I. The role of hyaluronic acid)

-, AND SAJDERA, S. W. (1969) J. biol. Chem., 244, 2384 (Protein polysaccharide complex from bovine nasal cartilage: the function of glycoprotein in the formation of aggregates)

HeINEGARD, D. (1973) Chemica Scripta, 4, 199 (Automated procedures for the determination of protein, hexose and uronic acid in column effluents)

Lyons, H., Jones, E., Quinn, F. E., AND Sprunt, D. H. (1964) Proc. Soc. exp. Biol., 115, 610 (Protein-polysaccharide complexes of normal and herniated human intervertebral discs)

,,,$----(1966) \mathrm{J}$. Lab. clin. Med., 68, 930 (Changes in the protein polysaccharide fractions of nucleus pulposus from human intervertebral disc with age and disc herniation)

MCDEvitT, C. A., AND MUIR, H. (1974) 'The proteoglycans of articular cartilage in early experimental osteoarthrosis' in 'Protides of Biological Fluids', Vol. XXII p. 269. Pergamon, London

NAylor, A., Shentall, R. D., AND West, D. C. (1974) 'Current investigations on the biochemical aspects of intervertebral disc degeneration and herniation' in 'Biopolymere und Biomechanik von Bindegewebssystemen,' ed. F. Hartmann, p. 77. Springer, Berlin.

SIMUNEK, Z., AND MUIR, H. (1972a) Biochem. J., 126, 515 (Changes in the protein-polysaccharides of pig articular cartilage during prenatal life, development and old age)

,--1 (1972b) Biochem. J., 130, 181 (Proteoglycans of the knee-joint cartilage of young normal and lame pigs)

Swann, D. A., AND Balazs, E. A. (1966) Biochim. biophys. Acta., 130, 112 (Determination of the hexosamine content of macromolecules with manual and automated techniques using the p-dimethylaminobenzaldehyde reaction)

Tsiganos, C. P., Hardingham, T. E., AND MUIR, H. (1971) Biochim. biophys. Acta., 229, 529 (Proteoglycans of cartilage: an assessment of their structure)

- AND MUIR, H. (1969a) Biochem. J., 113, 879 (Studies on protein-polysaccharides from pig laryngeal cartilage-extraction and purification)

,$--(1969 \mathrm{~b})$ Biochem. J., 113, 885 (Studies on protein-polysaccharides from pig laryngeal cartilageheterogeneity, fractionation and characterisation)

- (1973) 'Proteoglycan aggregation in different types of cartilage and its dependence on age' in 'Connective Tissue and Ageing', Vol. 1, p. 132. Excerpta Medica, Amsterdam

WOESSNER, J. F. (1961) Arch. Biochem., 93, 440 (The determination of hydroxyproline in tissue and protein samples containing small proportions of thisimino acid) 